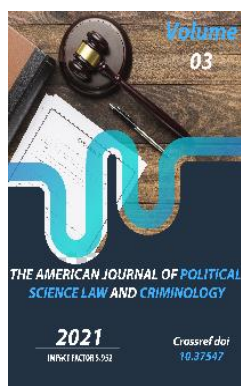

\title{
Family-Legal Methods Of Protecting The Rights Of Children When Their Parents Involve Them In Begging In The Republic Of Uzbekistan
}

Dinara Babajanova

PhD In Law, Tashkent State University Of Law, Uzbekistan

Journal Website: https://theamericanjou rnals.com/index.php/ta jpslc

Copyright: Original content from this work may be used under the terms of the creative commons attributes 4.0 licence.

\section{ABSTRACT}

This article discusses the issues of parents who involve their minor children in such types of antisocial behavior as begging. The author analyzes the terminology, the reasons for the occurrence of such a negative phenomenon, the existing legislative norms which provide for administrative and criminal liability, the ineffectiveness of these norms in resolving the issue of punishing such parents. The author of the article comes to the conclusion that it is necessary to study each specific case of parents involving their children in begging and providing appropriate assistance to the family.

\section{KEYWORDS}

Minor children, antisocial behavior, begging, children's rights, protection of rights, deprivation of parental rights, trusteeship, and guardianship.

\section{INTRODUCTION}

In the modern world, we often encounter such vociferous slogans as "protection of children's rights", "children are our future", "decent upbringing and maintenance of children", "we are against child labor", and many more. These words are already frequently used that few people pay due attention to them. A lot of work has been done in the Republic of Uzbekistan to ensure the protection of children's rights, as well as special bodies for their protection, upbringing, education has been created, a number of normative legal acts have been adopted, and international acts (for example, the UN Convention on the Rights of the Child [1]) for the protection of children's rights have been ratified.

In 2020, the position of the Deputy Commissioner for Human Rights of the Oliy 
Majlis of the Republic of Uzbekistan (Ombudsman) - the Commissioner for Children's Rights was introduced in the Republic of Uzbekistan [2], and a Public Council for the Protection of Children's Rights was established under the Commissioner in order to monitor the observance of the rights, freedoms and legitimate interests of the child.

But all these actions lose their meaning when we encounter a child begging on the street.

Begging is a negative phenomenon in a society that threatens public morality. O. A. Analyzing this issue, Dizer [3] argues that the measures taken to protect public morality from threats associated with begging are ineffective, and the result of applying the norms of legislation is zero.

By I. F. To Safaryanov [4] begging is a parasitic form of life activity, begging for money or other tangible and intangible values from strangers. Without bringing anything positive to society, the participants of this phenomenon most often generate harmful and negative events. They can manifest themselves in undermining social balance, violating public order and, even worse, in encroaching on the rights of other citizens.

Begging is a form of child labor, an unacceptable practice according to the United Nations and the International Labor Organization [5]. In addition, it is a violation of the fundamental rights of the child, especially the right to education, the right to good health and the right to mental and physical development [6]. Studies show that child labor affects children's academic performance because they have low academic performance in school [7].
Nowadays, it is not uncommon for parents to involve children in such anti-social behavior as begging, by actively asking for money on the streets, engaging in the sale of small household goods, using young children, or disabled people. Of course, the Republic of Uzbekistan has already adopted a number of normative legal acts to combat begging, including the Criminal Code of the Republic of Uzbekistan (article 127-1. Begging-introduced in 2019), the Code of the Republic of Uzbekistan on Administrative Responsibility (article 188-3. Begging - introduced in 2019). However, these norms, which provide for administrative and criminal liability of parents when committing the above-mentioned offenses and crimes, in no way facilitate the consideration of children. Since the sanction of article 188-3 of the Code provides for the imposition of a fine in the amount of 1 to 10 basic calculated values, or arrest for up to 15 days, and article 127-1 of the Criminal Code provides for punishment in the form of mandatory community service, correctional labor, restriction of liberty or imprisonment.

The assumption that the application of these sanctions against parents will protect the rights of children is erroneous, although it is quite legitimate. Since the consequences of the application of these sanctions will have a negative impact on the children themselves. Firstly, children will be left without a parent (which already contradicts the basic principles of family legislation), perhaps his only close person when applying a sanction in the form of arrest or imprisonment; secondly, a parent forced to pay a fine will face the problem of paying it and will be forced to look for a source of income again, in those conditions when he already has nothing to feed his children. 
The above-mentioned provisions prove the ineffectiveness of the application of administrative and criminal law in relation to parents who are in a difficult life situation and involve their minor children in begging. O. A. comes to a similar conclusion. Dizer [3], claims that in the Russian Federation, in the vast majority of cases, an administrative penalty is imposed in the form of a warning against persons engaged in begging, since the application of a fine is ineffective since after receiving a copy of the decision on an administrative offense, the person does not pay it.

Studying the issues of the reasons for the involvement of minors in begging by parents, A. K. Teokharov [8] notes that the need to find additional earnings leads to the fact that parents pay less attention to their children, due to the inability to get a job, parents involve their children in begging, both jointly and alone, motivating their children that it is necessary to earn money for the purchase of food. Of course, in this case, parents do not always think about the psychological trauma and moral suffering of the child, which he experiences standing with an outstretched hand and being recognized by his acquaintances, friends, classmates.

The family legislation of the Republic of Uzbekistan also has its own specific sanctions (deprivation of parental rights-article 79 of the Family (ode) against parents who involve their children in anti-social behavior. Article 79 of the Family Code provides for grounds for depriving parents (or one of them) of parental rights, among which there is "abuse of their parental rights". It is precisely this point that falls under the actions of parents to involve their children in begging. That is, if the fact of involving a minor in antisocial behavior is established on the basis of an appeal from state bodies engaged in activities to protect the rights of children, parents (or one of them) may be deprived of parental rights.

In this case, the children remain with another parent, or are transferred to the guardianship and guardianship authority, which, according to the rules provided for by family legislation, decides on the placement of children left without parental care. And even in this case, we face negative consequences for children.

All the above-mentioned norms of administrative, criminal and family legislation in this problem contradict the basics of family law, the primary right of children - the right to live and be brought up in a family (article 65 of the Family Code). In addition, article 65 provides for the right of the child to ensure his interests, respect for his human dignity, as well as (article 67) to protection from abuse by parents. Here we are faced with a conflict of norms. On the one hand, we should adhere to the law and "punish" parents, but on the other hand, by punishing parents, we will violate the rights of children. In our opinion, in this situation, we should adhere to the proportionality and sufficiency of punishments, be guided by the criteria of the best interests of the child, and in addition, it is necessary to study the reasons for such behavior of parents and, as necessary, provide effective assistance to a family in a difficult life situation.

The best interests of the child is an institution of family law, which does not have specific criteria for assessing what is best for the child (to engage in begging and be with parents, or not to engage in this activity, but to lose 
parents and be brought up in orphanages). For the most part, the above institution is used directly by the courts themselves in law enforcement practice. And in each individual case, the actions of the court may be different.

Thus, based on the analysis, we came to the following conclusions:

1. Begging is an antisocial phenomenon that negatively affects society and the persons involved in it, which generates many other adverse consequences established by administrative and criminal law;

2. The involvement of children's parents in begging has its own reasons, among which the main one is the inability of the parent (parents) to feed their family due to the lack of earnings;

3. Neither criminal, nor administrative, nor family laws can give a concrete solution that satisfies everyone to establish the responsibility of parents for involving children in begging;

4. The institute of the best interests of the child does not have clearly defined criteria and for this reason, in each case, the courts should be guided solely on the basis of the available case materials.

\section{REFERENCES}

1. Конвенция о правах ребенка. Принята резолюцией 44/25 Генеральной Ассамблеи от 20 ноября 1989 года. https://www.un.org/ru/documents/decl_c onv/conventions/childcon.shtml

2. Постановление Президента Республики Узбекистан «О дополнительных мерах по совершенствованию системы защиты прав ребенка» №ПП-4736 от 29 мая 2020 года. // Национальная база данных законодательства, 29.05.2020 г., № 07/20/4736/0680.

3. Дизер Олег Александрович Законодательство Российской Федерации о защите общественной нравственности от угроз, связанных с бродяжничеством u попрошайничеством // Научный вестник Омской академии МВД России. 2017. №4 (67).

URL: https://cyberleninka.ru/article/n/zakonoda telstvo-rossiyskoy-federatsii-o-zaschiteobschestvennoy-nravstvennosti-ot-ugrozsvyazannyh-s-brodyazhnichestvom-i (дата обращения: 28.06.2021).

4. Сафарянов Ирик Фидаилевич Актуальные вопросы борьбы с попрошайничеством // Евразийская адвокатура. 2017. №4 (29). URL: https://cyberleninka.ru/article/n/aktualnye -voprosy-borby-s-poproshaynichestvom (дата обращения: 28.06.2021).

5. IPEC. (2015, June 10). World report on child labour 2015: Paving the way to decent work for young people. Retrieved April 15, 2015, from http://www.ilo.org/ipec/Informationresou rces/WCMS 358969/lang-en/index.htm

6. UNICEF. (2004). Childhood under threat: The state of the world's children 2005:. New York: Author.

7. John, F. (2015). Effects of child labour on participation in public primary education in Kayole Division, Nairobi County, Kenya (Masters Thesis). Kenyatta University, Nairobi, Kenya. 
The American Journal of Political Science Law and Criminology (ISSN - 2693-0803)

Published: July 30, 2021 | Pages: 14-18

Doi: https://doi.org/10.37547/tajpslc/Volume03Issue07-03

8. Теохаров А.К. Детерминация попрошайничества среди несовершеннолетних // Виктимология. 2017. №4 (14). URL: https://cyberleninka.ru/article/n/determin atsiya-poproshaynichestva-sredinesovershennoletnih (дата обращения: 28.06.2021). 